\title{
Rotifers and lower crustaceans from South-western Iceland
}

\author{
Vesela V. Evtimova ${ }^{\ddagger}$, Ivan S. Pandourski ${ }^{\ddagger}$ \\ ‡ Institute of Biodiversity and Ecosystem Research, Bulgarian Academy of Sciences, Sofia, Bulgaria
}

Corresponding author: Vesela V. Evtimova (vesela.evtimova@gmail.com)

Academic editor: Michelle Hamer

Received: 15 Dec 2015 | Accepted: 23 Feb 2016 | Published: 02 Mar 2016

Citation: Evtimova V, Pandourski I (2016) Rotifers and lower crustaceans from South-western Iceland.

Biodiversity Data Journal 4: e7522. doi: 10.3897/BDJ.4.e7522

\begin{abstract}
\section{Background}

Iceland has high availability of freshwater, and it is rich in brackish and coastal aquatic bodies. However, knowledge on rotifers and meiobenthic and planktonic crustaceans inhabiting these habitats is lacking, and the inland aquatic fauna in Iceland is relatively understudied in comparison with the fauna of adjacent marine ecosystems. The majority of past research focused on larger lakes with the exception of one study on rotifers from the 1950s (Bartoš 1951) and two more recent studies on crustacean fauna of shallow freshwater bodies (Novichkova et al. 2014, Scher et al. 2000). Data are particularly scarce for the south-western part of the country.
\end{abstract}

\section{New information}

We studied the composition of selected invertebrate taxa in various aquatic (marine, brackish and freshwater) habitats from South-western Iceland with a focus on Rotifera, Cladocera and Copepoda. Samples were collected from 12 localities, including marine interstitial, freshwater temporary shallow pools, swamps, wet mosses, springs, and lakes (both brackish and freshwater). We found 39 taxa in total. Rotifera dominated the sampled water bodies, followed by Copepoda and Cladocera. Three of the recorded taxa are new 
for Iceland, of which two are rotifers [Trichocerca cf. mucosa (Stokes, 1896) and T. vernalis (Hauer, 1936)], and one is a marine copepod (Cyclopina gracilis Claus, 1862). For some of the sampled localities (Sikið and Leirvogsvatn Lakes, and some of the smaller habitats) we present the first data on their microinvertebrate fauna.

\section{Keywords}

Rotifera, Cladocera, Copepoda, Iceland, new records, marine, brackish, freshwater

\section{Introduction}

Iceland is one of the countries with the highest freshwater availability according to UNEP's Vital water graphics (http://www.eoearth.org/view/article/152861/). Additionally, being an island, it is rich in coastal brackish and saline aquatic habitats. However, little is known about the microcrustaceans and rotifers inhabiting these numerous habitats. The freshwater fauna of Iceland is relatively understudied compared to the fauna of adjacent marine ecosystems. Exhaustive sampling of deep-sea fauna was conducted within the inter-Nordic BIOICE project. As a result, Apostolov (2011) recorded 32 copepod harpacticoids of which 20 are new for the fauna of Iceland.

The first data on freshwater microinvertebrate fauna of Iceland date back to the $19^{\text {th }}$ century (Guerne and Richard 1892a, Guerne and Richard 1892b). The first study on the rotifer fauna from the middle of the $20^{\text {th }}$ century listed 59 species or subspecies (Bartoš 1951). The majority of the available studies on inland water bodies focused on large lakes: Mývatn in the north-east (Örnólfsd and Einarsson 2004, Adalsteinsson 1979, Jónasson 1979, Lindegaard 1979); and Thingvallavatn (Antonsson 1992) and Kerið Lakes (Evtimova et al. 2014) in the south-west of the country. Recently scientists have become increasingly interested in the inland freshwater copepods and cladocerans from small freshwater bodies (Novichkova et al. 2014, Scher et al. 2000). Data on observed morphological variability and teratology of lower crustacean in subpolar environments, including Iceland, were presented by Sinev et al. (2012), Pandourski and Evtimova (2009), Pandourski and Evtimova (2006), Pandourski and Evtimova (2005). These aberrations affected the fifth pair of legs in calanoids, the posterior part of the body in cyclopoids, or the head and antennule in cladocerans.

Our study presents data on taxa composition of Rotifera, Cladocera, and Copepoda in various aquatic habitats from South-western Iceland, including marine interstitial, wet bryophytes, springs, brackish and freshwater ponds and lakes. 


\section{Materials and Methods}

Samples were collected from various aquatic habitats from South-western Iceland. The sampling sites included marine interstitial habitat, puddles, swamps, freshwater or brackish lakes (Table 1, Fig. 1). Rotifers and lower crustaceans were collected using a qualitative plankton net (type "Apstein", mesh size $38 \mu \mathrm{m}$ ) and a hand-held plankton net (mesh size 40 $\mu \mathrm{m})$. The hand-held plankton net was used for sieving the sand and rinsing the bryophytes in order to collect the invertebrates inhabiting these substrata. The material was fixed in $70 \%$ ethanol.

Table 1.

Locations and dates of sampling with coordinates and notes on water body type, habitat and substratum.

\begin{tabular}{|c|c|c|c|c|c|}
\hline Site & Date & Collection & Habitat/ & Notes & Coordinates \\
\hline No. & & method & $\begin{array}{l}\text { substratum } \\
\text { sampled }\end{array}$ & & \\
\hline 1 & 02.07.2004 & Sieving & $\begin{array}{l}\text { Marine interstitial, } \\
\text { coarse sand }\end{array}$ & $\begin{array}{l}\text { Garðskagaviti lighthouse; low } \\
\text { tide }\end{array}$ & $\begin{array}{l}64^{\circ} 04^{\prime} 57.68^{\prime \prime} \mathrm{N}, \\
22^{\circ} 41^{\prime} 36.08^{\prime \prime} \mathrm{W}\end{array}$ \\
\hline 2 & 08.07 .2004 & Hand-held net & $\begin{array}{l}\text { Brackish lake, water } \\
\text { column }\end{array}$ & $\begin{array}{l}\text { Bessastaðatjörn Lake, coastal, } \\
\text { shallow, coarse volcanic sand, } \\
\text { macrophytes; }\end{array}$ & $\begin{array}{l}64^{\circ} 06^{\prime} 26.02 " \mathrm{~N}, \\
21^{\circ} 59^{\prime} 43.79^{\prime \prime} \mathrm{W}\end{array}$ \\
\hline 3 & 29.06 .2004 & Hand-held net & $\begin{array}{l}\text { Freshwater swamp, } \\
\text { scraping overgrown } \\
\text { stones }\end{array}$ & $\begin{array}{l}\text { Small, c/a } 200 \text { m from } \\
\text { Sandgerði Marine Centre }\end{array}$ & $\begin{array}{l}64^{\circ} 02^{\prime} 41.29 " \mathrm{~N}, \\
22^{\circ} 42^{\prime} 45.64^{\prime \prime} \mathrm{W}\end{array}$ \\
\hline 4 & 29.06.2004 & Hand-held net & $\begin{array}{l}\text { Freshwater swamp, } \\
\text { near the bottom }\end{array}$ & $\begin{array}{l}\text { Small, beside Sandgerði } \\
\text { Marine Centre, towards the } \\
\text { sea; polluted }\end{array}$ & $\begin{array}{l}64^{\circ} 02^{\prime} 42.08^{\prime \prime} \mathrm{N}, \\
22^{\circ} 42^{\prime} 45.14^{\prime \prime} \mathrm{W}\end{array}$ \\
\hline 5 & 30.06 .2004 & Hand-held net & $\begin{array}{l}\text { Puddle overgrown } \\
\text { by grass }\end{array}$ & Beside Sandvíkurtjörn Lake & $\begin{array}{l}63^{\circ} 51^{\prime} 14.90 " \mathrm{~N}, \\
22^{\circ} 41^{\prime} 21.68 " \mathrm{~W}\end{array}$ \\
\hline 6 & 04.07 .2004 & Zooplankton net & $\begin{array}{l}\text { Freshwater lake, } \\
\text { water column }\end{array}$ & $\begin{array}{l}\text { Sikið Lake; west of Garður } \\
\text { Village }\end{array}$ & $\begin{array}{l}64^{\circ} 04^{\prime} 18.20 " \mathrm{~N}, \\
22^{\circ} 38^{\prime} 45.38^{\prime \prime} \mathrm{W}\end{array}$ \\
\hline 7 & 05.07 .2004 & Zooplankton net & $\begin{array}{l}\text { Freshwater lake, } \\
\text { water column }\end{array}$ & $\begin{array}{l}\text { Leirvogsvatn Lake, stoney } \\
\text { bottom, high transperancy, } \\
\text { oligotrophic, no macrophytes }\end{array}$ & $\begin{array}{l}64^{\circ} 12^{\prime} 07.42 " \mathrm{~N}, \\
21^{\circ} 27^{\prime} 44.05^{\prime \prime} \mathrm{W}\end{array}$ \\
\hline 8 & 05.07 .2004 & Zooplankton net & $\begin{array}{l}\text { Freshwater lake, } \\
\text { water column }\end{array}$ & $\begin{array}{l}\text { Small shallow, c/a 5-6 km } \\
\text { eastwards from Stardalur and } \\
35 \mathrm{~km} \text { north-east of Reykjavik }\end{array}$ & $\begin{array}{l}64^{\circ} 12^{\prime} 37.89^{\prime \prime} \mathrm{N}, \\
21^{\circ} 19^{\prime} 23.27^{\prime \prime} \mathrm{W}\end{array}$ \\
\hline
\end{tabular}




\begin{tabular}{|c|c|c|c|c|c|}
\hline 9 & 05.07 .2004 & Rinsing & Bryophytes & $\begin{array}{l}\text { Wet mosses near Öxaráfoss } \\
\text { waterfall, Pingvellir National } \\
\text { Park }\end{array}$ & $\begin{array}{l}64^{\circ} 15^{\prime} 56.50 " \mathrm{~N}, \\
21^{\circ} 07^{\prime} 02.94^{\prime \prime} \mathrm{W}\end{array}$ \\
\hline 10 & 05.07 .2004 & Hand-held net & $\begin{array}{l}\text { Freshwater lake, } \\
\text { water column }\end{array}$ & $\begin{array}{l}\text { Laugarvatn Lake, shallow, hot } \\
\text { springs on its shores; Arnes } \\
\text { County, Laugardalur Valley }\end{array}$ & $\begin{array}{l}64^{\circ} 13^{\prime} 06.26 " \mathrm{~N}, \\
20^{\circ} 43^{\prime} 40.61^{\prime \prime} \mathrm{W}\end{array}$ \\
\hline 11 & 05.07 .2004 & Rinsing & Spring, bryophytes & $\begin{array}{l}\text { Small peat spring, low water } \\
\text { temperature }\end{array}$ & $\begin{array}{l}64^{\circ} 18^{\prime} 24.79^{\prime \prime} \mathrm{N}, \\
20^{\circ} 12^{\prime} 20.82 " \mathrm{~W}\end{array}$ \\
\hline 12 & 05.07.2004 & Zooplankton net & $\begin{array}{l}\text { Freshwater lake, } \\
\text { water column }\end{array}$ & $\begin{array}{l}\text { Kerið Lake, neovolcanic crater } \\
\text { lake; Grimsnes area }\end{array}$ & $\begin{array}{l}64^{\circ} 02^{\prime} 26.36 " \mathrm{~N}, \\
20^{\circ} 53^{\prime} 05.50^{\prime \prime} \mathrm{W}\end{array}$ \\
\hline
\end{tabular}

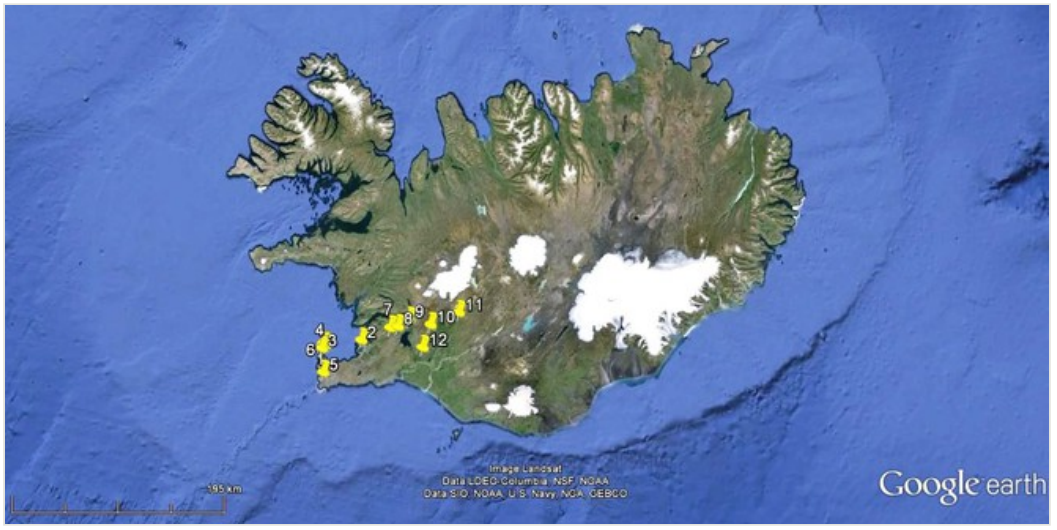

Figure 1.

Map of Iceland with sampling locations from 1 to 12 . For site numbers please see Table 1.

The specimens were mounted temporarily in a mixture of glycerin and ethanol and were identified to the lowest practicable level following Wallace and Snell (2010), Sørensen (2009), Segers (1995), Einsle (1993), Monchenko (1974), Manuylova (1964). Harpacticoids were identified by Dr Apostolov and presented in earlier works (Apostolov 2014, Apostolov 2007).

\section{Results}

A total of 39 taxa from Rotifera, Cladocera, and Copepoda were recorded from Southwestern Iceland during our study. The most diverse were the rotifers with 21 taxa belonging to nine families and two orders. We found 11 taxa of copepods which belonged to five families from three orders, and seven taxa of cladocerans from three families. Twelve associated invertebrate taxa were also found in our samples Table 2. 
Table 2.

List of taxa recorded from various habitats in South-western Iceland. For site numbers (No) please see Table 1.

\section{Group Taxon}

Rotifera

\section{Class Eurotatoria}

Order Ploima

Family Brachionidae

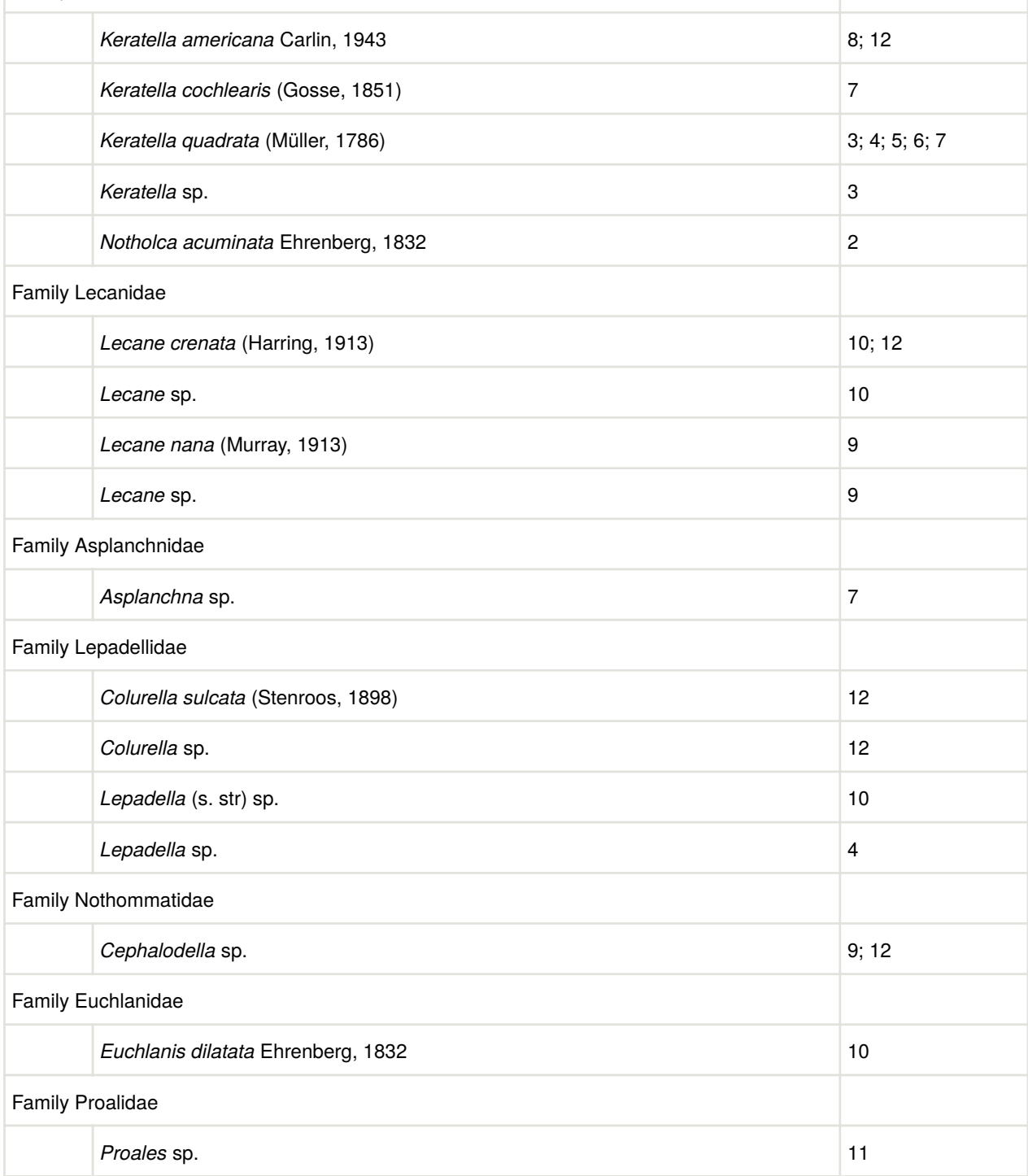

Site No.

(n)




\begin{tabular}{|c|c|}
\hline \multicolumn{2}{|l|}{ Family Trichocercidae } \\
\hline Trichocerca cf. mucosa (Stokes, 1896) & 6 \\
\hline Trichocerca vernalis (Hauer, 1936) & 8 \\
\hline Trichocerca sp. & 9 \\
\hline \multicolumn{2}{|l|}{ Order Flosculariaceae } \\
\hline \multicolumn{2}{|l|}{ Family Trochosphaeridae } \\
\hline Filinia terminalis (Plate, 1886) & 3 \\
\hline \multicolumn{2}{|l|}{ Class Branchiopoda } \\
\hline \multicolumn{2}{|l|}{ Order Anomopoda } \\
\hline \multicolumn{2}{|l|}{ Family Daphnidae } \\
\hline Daphnia pulex Leydig, 1860 & 6 \\
\hline \multicolumn{2}{|l|}{ Family Chydoridae } \\
\hline Acroperus harpae (Baird, 1835) & 8 \\
\hline Alona affinis (Leydig, 1860) & $8 ; 10 ; 12$ \\
\hline Alona quadrangularis (Müller, 1785) & $8 ; 10$ \\
\hline Chydorus sphaericus (Müller 1776) & 6 \\
\hline Chydorus sp. & 7 \\
\hline \multicolumn{2}{|l|}{ Family Macrothricidae } \\
\hline Macrothrix hirsuticornis Norman \& Brady, 1867 & 6 \\
\hline \multicolumn{2}{|l|}{ Class Maxillopoda } \\
\hline \multicolumn{2}{|l|}{ Order Calanoida } \\
\hline \multicolumn{2}{|l|}{ Family Temoridae } \\
\hline Eurytemora velox (Lilljeborg, 1853) & 2 \\
\hline \multicolumn{2}{|l|}{ Order Cyclopoida } \\
\hline \multicolumn{2}{|l|}{ Family Cyclopidae } \\
\hline Acanthocyclops vernalis (s. lat. Fischer, 1853) & $9 ; 12$ \\
\hline Cyclops abyssorum Sars, 1863 & 6 \\
\hline Diacyclops bisetosus (Rehberg, 1880) & 3; 9 \\
\hline Eucyclops serrulatus (Fischer, 1851) & $6 ; 8 ; 9 ; 10$ \\
\hline Megacyclops viridis (Jurine, 1820) & 8 \\
\hline Paracyclops fimbriatus fimbriatus (Fischer, 1853) & 8 \\
\hline
\end{tabular}




\begin{tabular}{|c|c|}
\hline \multicolumn{2}{|l|}{ Family Cyclopinidae } \\
\hline Cyclopina gracilis Claus, 1862 & 1 \\
\hline Copepodites & $1 ; 2 ; 6 ; 8 ; 10 ; 12$ \\
\hline Nauplii & $2 ; 6 ; 7 ; 10 ; 12$ \\
\hline \multicolumn{2}{|l|}{ Order Harpacticoida } \\
\hline \multicolumn{2}{|l|}{ Family Canthocamptidae } \\
\hline Bryocamptus (Arcticocamptus) cuspidatus cuspidatus (Schmeil, 1893) & $9 ; 11$ \\
\hline Bryocamptus (Bryocamptus) minutus (Claus, 1863) & 12 \\
\hline \multicolumn{2}{|l|}{ Family Ameiridae } \\
\hline Nitokra spinipes Boeck, 1865 & $2 ; 3$ \\
\hline \multicolumn{2}{|l|}{ Class Ostracoda } \\
\hline Ostracoda indet. & $1 ; 6 ; 9 ; 11$ \\
\hline \multicolumn{2}{|l|}{ Associated fauna } \\
\hline Amphipoda & 2 \\
\hline Acari & $5 ; 1 ; 9$ \\
\hline Acari (Halacaridae) & 5 \\
\hline Olygochaeta & 10 \\
\hline Polychaeta & 1 \\
\hline Colembolla & $5 ; 9$ \\
\hline Tardigrada & $1 ; 9$ \\
\hline Gastropoda & $1 ; 9$ \\
\hline Diptera larvae & $2 ; 9 ; 11$ \\
\hline Diptera (Chironomidae) larvae & $10 ; 12$ \\
\hline Nematoda & $9 ; 10 ; 12$ \\
\hline
\end{tabular}

Keratella quadrata (Müller, 1786) was recorded at five of the sampled localities, while the copepod Eucyclops serrulatus (Fischer, 1851) and the cladoceran Alona affinis (Leydig, 1860) were found at four and three of the sites, respectively. Twenty-eight taxa were recorded only at one of the 12 sampling locations. We recorded the highest diversity of rotifers and the lowest diversity of crustaceans from bryophytes near Öxaráfoss waterfall in Pingvellir National Park. 


\section{Discussion}

We present data on rotifers and lower crustaceans from 12 aquatic habitats. For two of the stations (6 and 7), the lakes Sikio and Leirvogsvatn, we present the first data on zooplankton, and possibly also the first data for some of the smaller habitats (e.g. stations $3,4,5,11)$. The majority of the recorded taxa either have a cosmopolitan distribution or are previously known from Iceland. For three of the recorded species we found no prevoius records in the available literature from Iceland: the rotifers Trichocerca cf. mucosa (Stokes, 1896) and T. vernalis (Hauer, 1936), and the copepod Cyclopina gracilis Claus, 1862. Rotifera dominated the sampled water bodies, followed by Copepoda and Cladocera. The most frequent taxon was the rotifer Keratella quadrata, previously recorded from Iceland by Bartoš (1951). All of the recorded rotifer species have a cosmopolitan distribution.

Many of the cladoceran taxa we recorded are frequently found in the arctic region. Acroperus harpae (Baird, 1835) is typical for the littoral fauna of freshwater lakes from the Holoarctic region (Novichkova et al. 2014, Sinev et al. 2012). Arctic populations of Macrothrix hirsuticornis Norman \& Brady, 1867 are known to have high densities of specimens that are characterised with longer bodies and greater number of eggs per female (Meijering 2003, Margaritora and Usai 1983, Meijering 1979). Macrothrix hirsuticornis and Alona quadrangularis (Müller, 1785) are widely distributed and often are found in arctic regions and similar environments, likely owing to the resistance of their diapausing eggs to very low temperatures (Meijering 2003). We found these two species in permanent freshwater lakes (stations 6,8 , and 10).

All of the freshwater cyclopoid crustaceans recorded have cosmopolitan distribution and have been previously recorded from Iceland. We found only one marine copepod Cyclopina gracilis Claus, 1862. It is very common in the North Atlantic Ocean (Carey 1992, Grainger and Mohammed 1991, Mohammed and Neuhof 1985) but previously has not been reported from Iceland. The dominant cyclopoid in our samples was Eucyclops serrulatus (Fischer, 1851). Cyclops abyssorum Sars, 1863 is known to be among the dominant copepods in the large Icelandic lakes and is an important structural element for their zooplankton assemblages (Novichkova et al. 2014, Antonsson 1992). According to Larsen and Røen (1964) and Scher et al. (2000) another common cyclopoid for Iceland is Megacyclops viridis (Jurine, 1820). We found both $C$. abyssorum and $M$. viridis as well but only from shallow freshwater lakes (sites 6 and 8 , correspondingly).

The two species of the harpactocoid genus Bryocamptus we recorded are associated with wet mosses (Evtimova et al. 2014, Apostolov 2007). Nitokra spinipes Boeck, 1865 can tolerate changes in salinity (Apostolov 2014) and was found from both brackish and freshwater habitats (sites 2 and 3). 


\section{Conclusions}

This manuscript presents faunistic data on microinvertebrate aquatic fauna, including new species records, from an understudied region where detailed data are still scarce. We found 39 taxa from 12 sites, and three of the recorded taxa are new for Iceland. Moreover, here we present first data on the zooplankton of Sikio and Leirvogsvatn Lakes. Future studies in the region would likely further enrich our knowledge on the composition and origin of microinvertebrate aquatic fauna of the island.

\section{Acknowledgements}

The study was financed through Improving the Human Potential Programme of the European Union, Access to Research Facilities (ARI). We thank Dr Gudmundur Vidir Helgason (Institute of Biology, University of Iceland) for organisation and assistance with fieldwork in Iceland.

\section{Funding program}

Improving the Human Potential Programme of the European Union, Access to Research Facilities (ARI), within FP5.

\section{Project}

Taxonomy, faunistics and zoogeography of brackish and freshwater copepods (Crustacea) from the Reykjanes peninsula, Iceland (June 2004 - September 2007).

\section{Hosting institution}

Sanðgerdi Marine Centre and the Institute of Biology, University of Iceland.

\section{Author contributions}

Both authors contributed equally to samples collection and processing, and the writing of the manuscript. 


\section{References}

- $\quad$ Adalsteinsson H (1979) Zooplankton and Its Relation to Available Food in Lake Mývatn. Oikos 32(1-2): 162. DOI: $\underline{10.2307 / 3544226}$

- Antonsson Ú (1992) The Structure and Function of Zooplankton in Thingvallavatn, Iceland. Oikos 64: 188-221. [In English]. DOI: 10.2307/3545052

- Apostolov A (2007) Copepodes harpacticoïdes des eaux douces de l'Islande. Rivista di idrobiologia 43: 96-113.

- $\quad$ Apostolov A (2011) Les harpacticoïdes marins (Crustacea, Copepoda) d'Islande. Libra scorp, Burgas, 367 pp. [In French]. [ISBN 978-954-471-163-4]

- Apostolov A (2014) Contribution to the study of marine harpacticoid fauna (Crustacea, Copepoda) of Iceland. ZooNotes 62: 1-5.

- Bartoš E (1951) Rotatoria of the Czechoslovakian Iceland-expedition. Hydrobiologia 3 (3): 244-250. DOI: $10.1007 / \mathrm{bf00043716}$

- Carey A (1992) The ice fauna in the shallow southwestern Beaufort Sea, Arctic Ocean. Journal of Marine Systems 3 (3): 225-236. DOI: 10.1016/0924-7963(92)90002-p

- $\quad$ Einsle U (1993) Crustacea, Copepoda: Calanoida und Cyclopoida. Sueßwasserfauna von Mitteleuropa. 8 / 4 - 1. Gustav Fischer Verlag, 210 pp.

- Evtimova V, Pandourski I, Apostolov A (2014) First study on the zooplankton of the Kerid (Kerið) Crater Lake, Iceland. ZooNotes 55: 1.

- Grainger EH, Mohammed AA (1991) Some diagnostic characters of copepodid stages of the cyclopoid copepod Cyclopina schneideri T. Scott and adults of arctic marine Cyclopinidae . Canadian Journal of Zoology 69 (9): 2365-2373. DOI: 10.1139/z91-333

- Guerne d, Richard J (1892a) Sur la faune des eaux douces de l'Islande. Comptes Rendus de l'Académie des Sciences, Paris 114: 1-3. [In French].

- $\quad$ Guerne d, Richard J (1892b) Voyage de M. Charles Rabot en Islande. Sur la faune des eaux douces. Bulletin de la Société zoologique de France 17: 75-80. [In French].

- Jónasson P (1979) Ecology of eutrophic, subarctic Lake Myvatn and the River Laxá. Oikos 32 (1-2): 1-308.

- $\quad$ Larsen F, Røen U (1964) Entomostraca from the Skaftafell area, Iceland. Videnskabelige Meddelelser dansk naturh Foren 127: 135-149.

- $\quad$ Lindegaard C (1979) The Invertebrate Fauna of Lake Mývatn, Iceland. Oikos 32: 151. DOI: $10.2307 / 3544225$

- Manuylova E (1964) Branchiopod crutaceans (Cladocera) from the USSR. Nauka, Moskow, Leningrad, 327 pp. [In Russian].

- Margaritora F, Usai MC (1983) Systematic and ecological data on Macrothrix hirsuticornis Norman and Brady (Crustacea, Cladocera) in Lake Campo Felice (Apennine Abruzzi). Bolletino di zoologia 50: 137-142. DOI: 10.1080/112500083094394 $\underline{37}$

- Meijering M (1979) Life cycle, ecology, and timing of Macrothrix hirsuticornis Norman and Brady (Cladocera, Crustacea) in Svalbard. Polarforschung 49: 157-171.

- Meijering P (2003) The long-lasting resistence of diapausing eggs from Arctic Cladocera frozen at $-18^{\circ} \mathrm{C}$. Polish Polar Research 24 (2): 167-172.

- Mohammed AA, Neuhof V (1985) Arctocyclopina pagonasta, a new genus and species of the family Cyclopinidae (Cyclopoida, Copepoda) from the annual sea ice in the 
Canadian Arctic. Canadian Journal of Zoology 63 (10): 2389-2394. DOI: 10.1139/ z85-353

- Monchenko V (1974) Fauna Ukraini, Cyclopidae . 27. Naukova dumka, Kiev, 452 pp. [In Ukrainian].

- Novichkova A, Chertoprud E, Gíslason GM (2014) Freshwater Crustacea (Cladocera, Copepoda) of Iceland: taxonomy, ecology, and biogeography. Polar Biology 37 (12): 1755-1767. [In English]. DOI: 10.1007/s00300-014-1559-x

- Örnólfsd EB, Einarsson Á (2004) Spatial and temporal variation of benthic Cladocera (Crustacea) studied with activity traps in Lake Myvatn, Iceland. Aquatic Ecology 38 (2): 239-257. DOI: 10.1023/b:aeco.0000032059.99310.d3

- Pandourski I, Evtimova V (2005) Teratological morphology of copepods (Crustacea) from Iceland. Acta Zoologica Bulgarica 57 (3): 305-312.

- Pandourski I, Evtimova V (2006) First record of Eurytemora velox (Lilljeborg, 1853) (Crustacea, Copepoda, Calanoida) in Iceland with morphological notes. Historia naturalis bulgarica 17: 35-38.

- Pandourski I, Evtimova V (2009) Morphological variability and teratology of lower crustaceans (Copepoda and Branchiopoda) from circumpolar regions. Acta Zoologica Bulgarica 61 (1): 55-67.

- Scher O, Defaye D, Korovchinsky N, Thiéry A (2000) The Crustacean fauna (Branchiopoda, Copepoda) of shallow freshwater bodies in Iceland. Vestnik zoologii 34 (6): 11-25. [In English].

- $\quad$ Segers H (1995) Rotifera, Volume 2: The Lecanidae (Monogononta). Guides to the identification of the microinvertebrates of the continental waters of the world, 2. SPB Academic publishing, $226 \mathrm{pp}$. [In English].

- Sinev A, Zawisza E, Einarsson Á (2012) Usual stable morphotype of Acroperus harpae (Baird, 1834) from lake Mývatn, Iceland (Cladocera: Anomopoda: Chydoridae) revealed by paleolimnological studies. Studia Quaternaria 29: 3-7. URL: http://

www.studia.quaternaria.pan.pl/pdfs/sq29/03 07 sq29 zmn.pdf

- $\quad$ Sørensen M (2009) Rotifera of the Gulf of Mexico. In: Felder DL, Camp DK (Eds) Gulf of Mexico - Origins, Waters, and Biota. Biodiversity. Texas A\&M Press, College Station, Texas, 533-537 pp.

- Wallace R, Snell T (2010) Rotifera. Ecology and Classification of North American Freshwater Invertebrates. Academic Press, 173-188 pp. URL: http://dx.doi.org/10.1016/ b978-0-12-374855-3.00008-x DOI: 10.1016/b978-0-12-374855-3.00008-x 